Article

\title{
Resource Recovery from Waste: Restoring the Balance between Resource Scarcity and Waste Overload
}

\author{
Anne P. M. Velenturf * (D) and Phil Purnell \\ Resource Recovery from Waste Programme, School of Civil Engineering, University of Leeds, Leeds LS2 9JT, UK; \\ P.Purnell@leeds.ac.uk \\ * Correspondence: A.Velenturf@leeds.ac.uk; Tel.: +44-1134-32279
}

Received: 13 July 2017; Accepted: 1 September 2017; Published: 8 September 2017

\begin{abstract}
Current societal patterns of production and consumption drive a twin environmental crisis of resource scarcity and waste overload. Positioning waste and resource management in the context of ecosystem stewardship, this article relates increasing resource demand and waste production to the violation of planetary boundaries and human rights. We argue that a transition towards a circular economy (CE) that contributes to a resilient environment and human well-being is necessary to achieve the UN Sustainable Development Goals. The transition requires scientific and technological progress, including the development of low-energy biogeochemical technologies for resource recovery, and multi-dimensional value assessment tools integrating environmental, social, and economic factors. While the urgency to adopt a CE is well-recognised, progress has been slow. Coordinated change is required from multiple actors across society. Academia can contribute through participatory action research. This article concludes with the participation strategy of the Resource Recovery from Waste programme, aiming for changes in mentality, industry practices, and policies and regulations in the waste and resource management landscape in the UK.
\end{abstract}

Keywords: waste and resource management; ecosystem stewardship; planetary boundaries; human rights; UN Sustainable Development Goals; sustainable production and consumption; circular economy; participation processes; stakeholder engagement; transdisciplinary research

\section{Introduction}

If our society continues in its current patterns of production and consumption, we will soon face a twin environmental crisis of resource scarcity and waste overload [1-4]. In 2010, UNEP [2] estimated that 11.2 billion tonnes of waste-roughly 2 tonnes for every person on the planet-was collected; the uncollected waste volume is likely to be of similar magnitude. Our current over-reliance on emission or disposal rather than reuse or recycling causes unsustainable impacts on environmental quality and human health, which are expected to worsen with the growing global population adopting unsustainable consumption patterns.

Resolving the paradox of depleting virgin resources to make new products, whilst allowing these resources to languish in discarded products that we must manage as waste, is increasingly important in the transition towards a more sustainable circular economy (CE). Here we argue that waste and resource management plays a key role in our current unsustainable society and hence transforming management practices is crucial in addressing global sustainability issues. Boundaries for maintaining long-term environmental and socio-economic stability have been crossed. Radical changes in the way that waste and resource flows are organised are necessary; not least to achieve the UN Sustainable Development Goals (UN SDGs) [5].

Recognising the necessity for such economic change, the Resource Recovery from Waste (RRfW) programme was funded aiming '... to gather the evidence to improve the way that waste is valued as a 
resource, based on a whole system approach, i.e., incorporating environmental and social benefits and not just economic' ([6] p. 1). This research programme develops interdependent technical and social solutions for waste and resource management as part of a $\mathrm{CE}$, striving to maximise societal benefits. This article aims to explain the starting position i.e., the rationale for initiating RRfW, detailing the necessity for a $\mathrm{CE}$ that contributes to a resilient environment and human well-being, and provide grounding for delivering projects and overarching programme activities through close transdisciplinary partnerships. Section 2 places waste and resource management in the context of ecosystem stewardship. Sections 3 and 4 connect waste and resource management to environmental and social boundaries. Section 5 discusses economic models, followed by areas where scientific and technological progress is particularly needed in Section 6. Section 7 argues that progress towards sustainable waste and resource management has been slow and proposes participation process management, and participatory action research specifically, to engage the multiple stakeholders involved in the transformative changes that are required. We conclude with the participatory strategy adopted by RRfW to illustrate how academia can play a leading role in the transition towards a CE.

\section{Ecosystem Stewardship and Resource Management}

A healthy environment is essential for human well-being. At the most fundamental level, people depend on the environment to meet basic human needs including access to clean water, food and shelter. It is also widely accepted that the human species, like no other, exerts its capacity to engineer the environment; this becomes more and more evident as increasing population, income, and consumption couples with increased resource extraction and waste production [7]. The impacts are of such magnitude that some argue we have entered a new geological era: the Anthropocene [8].

Ecosystems can be understood as the communities of various species' populations within their physical environment, and the flows of energy and matter between the living and non-living elements in the system. Ecosystem stewardship recognises the human species as integral part of the ecosystem, and argues that people carry a responsibility to manage the environment such that society's use of resources is compatible with the ecosystem's capacity to sustain services [9-11]. The (resource) economy is embedded in human society, which in turn is dependent on the biophysical environment of the ecosystem (Figure 1).

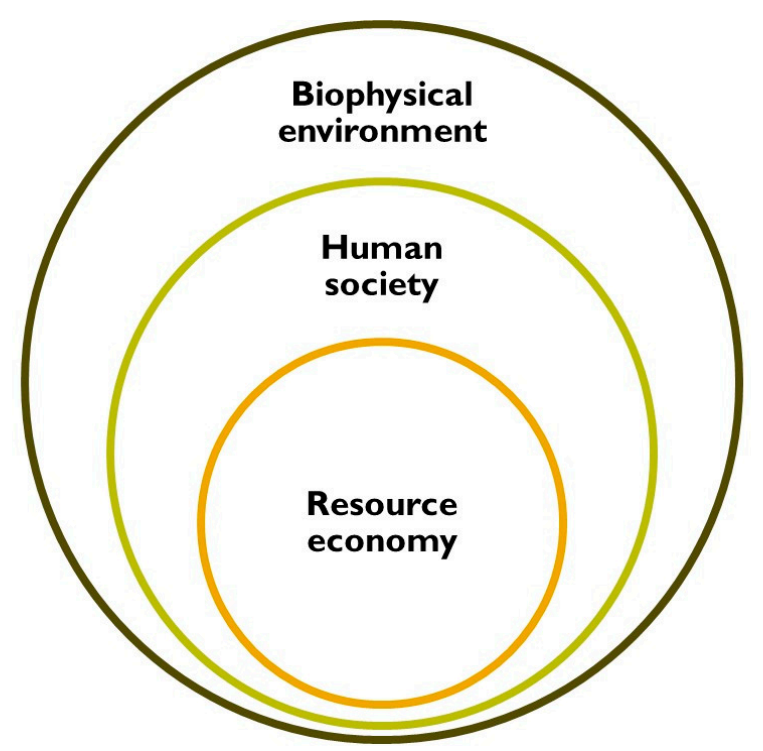

Figure 1. Ecosystem stewardship recognises people, and the way they organise society and resource flows, as an integral part of the biophysical environment. 
The next two sections relate waste and resource management to biophysical and societal boundaries, emphasising the key role of waste and resource management in achieving UN SDGs [5]. Out of the 17 goals, 12 directly contain targets to improve waste and resource management; others, such as education, policy, and finance, can indirectly enhance sustainable waste and resource management. The global goals on affordable and clean energy (Goal 7), clean water and sanitation (6), and life below water and on land (14 and 15) contain the highest proportions of targets aiming to alter waste and resource flows in our economy (Figure 2). Various targets propose far-reaching changes for industry, including the following:

- $\quad$ 6.3: By 2030, improve water quality by reducing pollution, eliminating dumping, and minimizing release of hazardous chemicals and materials, halving the proportion of untreated wastewater and substantially increasing recycling and safe reuse globally.

- 9.4: By 2030, upgrade infrastructure and retrofit industries to make them sustainable, with increased resource-use efficiency and greater adoption of clean and environmentally sound technologies and industrial processes, with all countries taking action in accordance with their respective capabilities.

- 12.1: Implement the 10-Year Framework of Programmes on Sustainable Consumption and Production Patterns, all countries taking action, with developed countries taking the lead, taking into account the development and capabilities of developing countries.

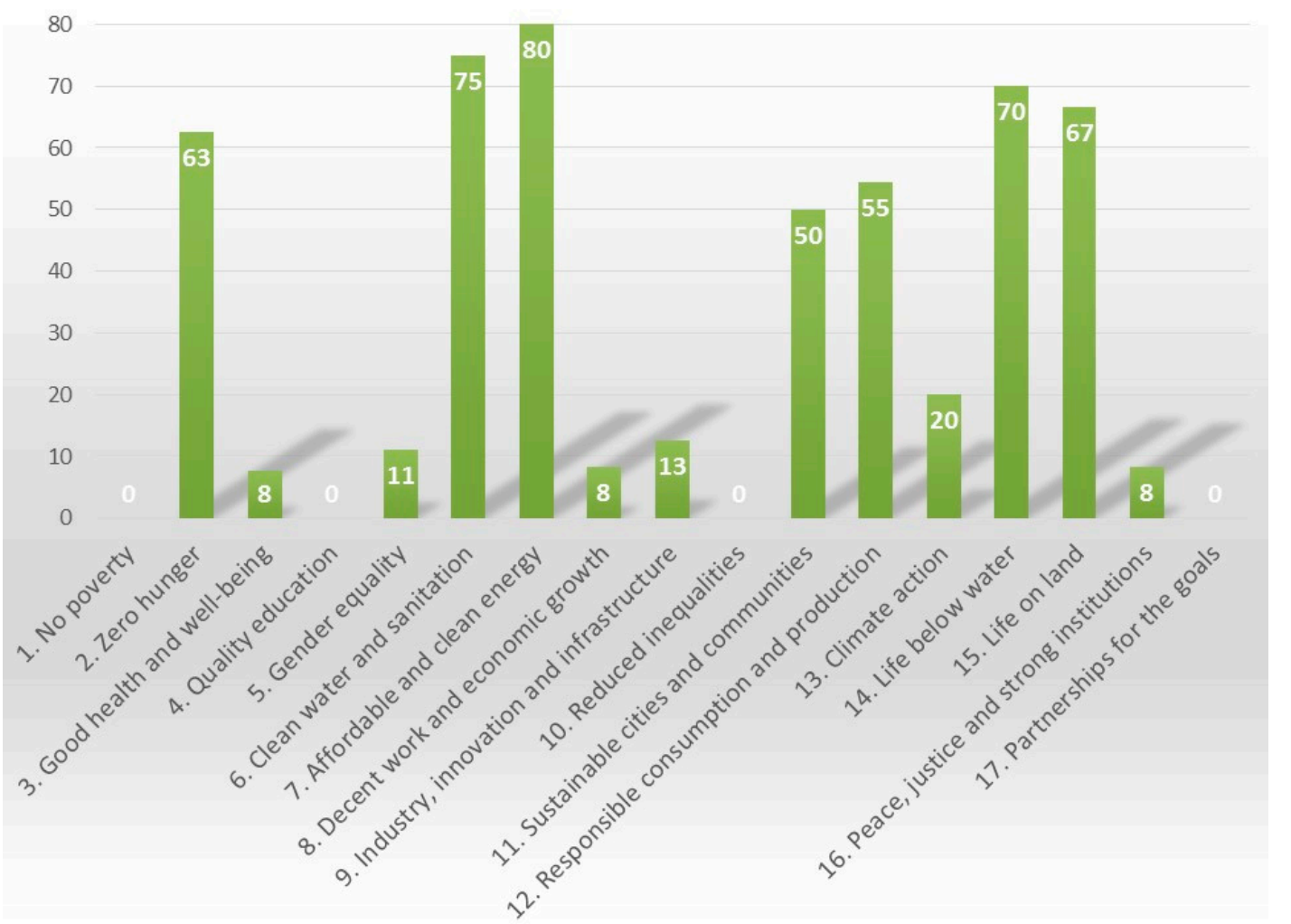

Figure 2. Percentage of targets directly on waste and/or resource management in each UN SDG.

The next sections will detail the interrelations between waste and resource management and stewardship of our environment and societal progress, emphasising the scale of the newly acquired responsibilities connected to waste management in its broadest sense. 


\section{Crossing Planetary Boundaries}

Since the mid-20th century, people have changed ecosystems at an unprecedented speed and scale, driven by the increasing demand for food, water, timber, fibre, and fuel, i.e., growing resource use, and the development of the supporting infrastructure for these resource flows and the discharge of wastes [9]. While the growing resource economy has generally increased welfare in the short term, important negative impacts have emerged that will impede both the long-term well-being of people and the resilience of the biophysical environment.

Nine planetary boundaries have been identified, outlining the 'safe operating space' for humanity (Table 1). Crossing these boundaries could cause catastrophic environmental change, destabilising global ecosystems into states that are less desirable for people [12].

Table 1. The nine planetary boundaries outlining the safe operating space for humanity are directly linked to waste (in its broadest sense including emissions of pollutants into the environment) and resource management [12].

\begin{tabular}{|c|c|}
\hline Planetary Boundary & Relation to Waste and Resource Management \\
\hline Climate change & $\begin{array}{l}\text { Mainly driven by use of fossil fuels and land use changes such as deforestation; } \\
\text { reflected in } \mathrm{CO}_{2} \text { concentration, increased number of heatwaves and heavy rainfall } \\
\text { events, droughts, and polar ice mass loss [13]. }\end{array}$ \\
\hline Ozone depletion & $\begin{array}{l}\text { Caused by a combination of anthropogenic ozone-depleting substances such as CFCs } \\
\text { and nitric acid. }\end{array}$ \\
\hline Ocean acidification & $\begin{array}{l}\text { Carbon dioxide emissions from fossil fuel use leads to ocean acidification by } \\
\text { dissolving in sea water as well as carbon uptake by marine organisms. }\end{array}$ \\
\hline Biogeochemical loading & $\begin{array}{l}\text { Atmospheric } \mathrm{N}_{2} \text { is converted into biologically active forms through industrial } \\
\text { ammonia production, crop production, and burning of fossil-fuels and biomass. } \\
\text { Most } \mathrm{N}_{2} \text { intended for crop fertilisers dissipates into the (aquatic) environment where } \\
\text { it causes pollution. While P dissipates into the environment through natural } \\
\text { processes, the human use of detergents and sewage effluent flows adds to P loading } \\
\text { in the (aquatic) environment. }\end{array}$ \\
\hline Land system change & $\begin{array}{l}\text { Land conversion to crop land and agricultural intensification. Controllable by only } \\
\text { using most productive areas for crops, limiting land degradation, maintaining } \\
\text { irrigation water flows, and managing competing land-uses including urbanisation } \\
\text { and biofuel production as well as managing consumption patterns and } \\
\text { waste generation. }\end{array}$ \\
\hline $\begin{array}{l}\text { Rate of biodiversity loss } \\
\text { (biosphere integrity [13]) }\end{array}$ & $\begin{array}{l}\text { Including genetic and functional diversity [13]. Humanity accelerated biodiversity } \\
\text { loss by } 100-1000 \text { times Earth's historic extinction rates. Species loss is driven by } \\
\text { habitat loss and degradation, overexploitation, species introductions, climate change, } \\
\text { and pollution. }\end{array}$ \\
\hline Global freshwater use & $\begin{array}{l}\text { Temporal and spatial flows of freshwater are mainly controlled by people, affecting } \\
\text { other resource flows such as access to food and precipitation patterns. }\end{array}$ \\
\hline $\begin{array}{l}\text { Atmospheric aerosol } \\
\text { loading }\end{array}$ & $\begin{array}{l}\text { Global concentrations of aerosols have doubled due to human activity in the past } \\
250 \text { years, impacting precipitation patterns and human health (especially respiratory } \\
\text { diseases). Aerosol loading can also impact agricultural productivity, forest cover, and } \\
\text { freshwater fish. }\end{array}$ \\
\hline Chemical pollution & $\begin{array}{l}\text { This includes pollution through heavy metals, organic compounds of human origin, } \\
\text { and radioactive compounds, impacting human health and the physiology of other } \\
\text { life. Exposure can be direct through air, water, and soil but also through } \\
\text { accumulation in food chains. Effects are not necessarily directly lethal but can disrupt } \\
\text { endocrine systems etc. For some chemicals, planetary boundaries have been crossed } \\
\text { (e.g., POPs such as dioxins and DDT); however, determining whether the overall } \\
\text { planetary boundary has been crossed is not possible yet due to the large range and } \\
\text { complexity of chemicals produced by humanity. }\end{array}$ \\
\hline
\end{tabular}

With four boundaries already crossed-for climate change, biogeochemical loading, biosphere integrity [9], and land system change, the latter of which was added when relations to the first three crossed boundaries were reexamined [13]—action to return to and/or stay within the safe operating 
space is urgent. First, atmospheric carbon dioxide $\left(\mathrm{CO}_{2}\right)$ concentration increased by ca. $32 \%$ in the past 250 years, driven by burning fossil fuels and land use changes. Over half of industrial $\mathrm{CO}_{2}$ emissions are associated with the processing of primary materials such as steel, timber, aluminum, glass, paper, and concrete [14]. Avoiding the dissipation of the technical properties of these materials into waste by developing processes to recover, reuse, and recycle them would significantly reduce carbon emissions. Moreover, the waste management sector directly produced 3-5\% of total anthropogenic greenhouse gas emissions in 2005 [15]. Thus, the waste management sector has the opportunity to move from being a minor source to a major saver of carbon by preventing waste arisings and recovering resources from waste, avoiding emissions from other sectors [16].

Moving on to the second boundary crossed, for biogeochemical loading, biologically active nitrogen flows (converted from $\mathrm{N}_{2}$ in the atmosphere) have roughly doubled, and phosphorous flows (converted from phosphate rock) tripled in the past 50 years [12]. These increases were mainly driven by the use of synthetic fertilisers in agriculture; $90 \%$ of global demand for phosphorus is for food production and this demand is increasing [17]. Waste management can play a key role in closing loops of phosphorus flows [18]. With ca. $90 \%$ of the global water footprint attributable to agricultural products [19], development and adoption of new water treatment technologies recovering phosphorus and nitrogen (e.g., $[20,21])$ would constrain additional biogeochemical loading and reduce energy expenditure on primary sourcing of these nutrients.

Crossing of the third boundary, biodiversity loss which was later changed to biosphere integrity [13], is caused by habitat loss, climate change, overexploitation, and pollution [9] that has led to the mass-extinction of species, indicating the reduced capacity of the global ecosystem to sustain life. The factors driving biodiversity loss are directly linked to unsustainable resource use. Since direct reduction of the demand for food, water, timber, fibre, and fuel is unlikely given the growing global population, indirect reduction via sustainable production and consumption practices are key to limiting further biodiversity loss.

The ways in which resources are extracted, produced, used, and wasted are the routes via which we are crossing and approaching the planetary boundaries (Table 1). Therefore, transforming waste and resource management must play a key part in changing these self-destructive pathways. A more sustainable circular economy (CE) approach-further discussed in Section 5-would significantly reduce production of primary resources, freshwater demand and quality, and carbon emissions; the associated improved waste management practices could limit environmental pollution and adverse effects on human health.

\section{Crossing Social Boundaries of Health and Well-being}

'It has long been recognized that a clean, healthy and functional environment is integral to the enjoyment of human rights, such as the rights to life, health, food, and an adequate standard of living' ([22] p. viii).

Environmental change impacts on human health and well-being through ecosystem services. Four types are identified [9]:

- $\quad$ provisioning services including those providing food, water, timber, and fibre;

- $\quad$ supporting services including soil formation, photosynthesis, and nutrient cycling;

- regulating services including managing the climate, floods, disease, wastes, and water quality; and

- cultural services including those with recreational, aesthetic, and spiritual benefits.

Humanity has already radically altered ecosystems such that about $60 \%$ of the capacity of ecosystem services have been degraded or are being used unsustainably [9]. Environmental degradation, especially in the form of anthropogenic climate change is already affecting, or is predicted to affect, billions of people through direct threats such as catastrophes and more gradual processes impeding access to clean water and food and provision of other primary needs, impacting rights to life, food, water, health, housing, and self-determination [22,23]. 
Overexploitation of natural resources and the discharge of wastes into the environment are driving the degradation of ecosystem services that have been identified as essential for supporting these most basic human rights (Table 2). A safe, healthy, and ecologically balanced environment is a human right in itself [24]. Further human rights associated with an adequate living environment include access to shelter, clothing, and other essential goods, good social relations and freedom of choice and action (further discussed below), and security (also see right to life in Table 2) [9].

Table 2. Ecosystem changes driven by waste and resource management are linked to threats to human rights.

\begin{tabular}{cl}
\hline Right to: & \multicolumn{1}{c}{ Relation to Environment and Waste and Resource Management } \\
\hline Life & $\begin{array}{l}\text { Depending on access to other fundamental rights to food, water, health and shelter. } \\
\text { Personal safety and security from natural and man-made disasters (linked to e.g., } \\
\text { climate change and changing water flows). }\end{array}$ \\
\hline Water & $\begin{array}{l}\text { Water and sanitation are recognised as fundamental to physical and mental health and } \\
\text { the right to life, disease prevention, and living a life in dignity. }\end{array}$ \\
\hline Food & $\begin{array}{l}\text { Food production depends on environmental quality such as climate, soil, water and } \\
\text { biodiversity. }\end{array}$ \\
\hline \multirow{2}{*}{ Health } & $\begin{array}{l}\text { Related to changes in land use, migration, and environmental degradation giving } \\
\text { space for spreading of diseases. } \\
\text { Linked in particular to access to clean air and water. }\end{array}$ \\
\hline
\end{tabular}

Intensifying resource exploitation has been associated with economic growth and welfare increases, especially in highly industrialised countries [4,24]. However, the benefits of resource exploitation are not equally shared around the globe, with many communities still living in poverty. This inequality fundamentally stems from unequal access to resources. The transition towards more sustainable resource management should contribute to solving these inequalities; see, for example, the ambition raised in UN SDG 12.1 on the 10-Year Framework of Programmes on Sustainable Consumption and Production Patterns integrating poverty reduction and shared prosperity $[5,25,26]$.

While changing management of resources upstream of the waste production point is crucial for human rights, more work also needs to be done downstream. Waste management impacts directly on the rights to a safe environment, human health, clean water, healthy food, and safe shelter. The effects are global, and evidently felt by both industrialised and developing countries. For example, outdoor air pollution is estimated to cause 40,000 deaths in the UK per year [27], while over 750 deaths related to management of dumpsites were recorded globally within just seven months [28]. Monitoring the societal impacts of waste can be challenging as its effects on the environment (and by extension, human health) are changing in complex ways due to climate change and the introduction of new waste management processes, materials, components, and products [4,9].

Of particular concern are the relations between transport and disposal of dangerous wastes and human rights. Increases of hazardous wastes and associated illegal trafficking and dumping have long been a special focus of human rights organisations, recognised as a threat to human rights to life and health [24]. In many cases, waste materials generated in developed countries are sent for reprocessing to countries where labour protection laws are minimal and/or poorly enforced. Negative social impacts will accrue that may or may not be balanced by the positive social impacts of providing employment and economic opportunities [29].

Recovering resources from wastes must also be approached with care for the environment and human rights. Recovery processes can present the opportunity for contaminants, including persistent chemicals, to pass into the ecosystem and impact land, air, water, and the food chain [30]. For example, current use of antibiotics in livestock farming and the spreading of manure to agricultural land has been linked to increasing antibiotic resistance in people, reinforced by increased waste water recycling and spreading of sewage sludge on agricultural land. While the implications of higher concentrations 
of pollutants and antimicrobial agents on human health are recognised, effects on the environment are less clear $[15,31,32]$. Critical assessment is necessary to ensure that resource recovery processes are truly sustainable.

Maintaining ecosystem services and a safe and healthy environment for humanity depends on people exercising their human rights. These include the right to information, public participation in decision-making, and access to justice; exercising those rights is enhanced by education [24]. The next sections turn to generating the required shared community-based, scientific and technological knowledge required in the transition to more sustainable waste and resource management practices.

\section{Economic Models of Waste and Resource Flows}

The current dominant way of organising waste and resource flows is the linear model. Resources are extracted or grown, processed into materials, components and products, consumed and then wasted. This creates the paradox in which humanity continues to deplete virgin resources whilst adding to waste management issues. A transition adopting an alternative economic model, that returns and/or maintains people's practices within fundamental environmental and human boundaries, is urgently needed. Supply chains need to be redesigned to prevent the technical, environmental, social, and economic value of materials from leaking into waste at any point in the product life cycle.

Various conceptual starting points have been proposed for designing such a system, e.g., the 'waste hierarchy' [33], 'industrial ecology' [34], 'zero waste', 'closed loop' systems (e.g., https:/ / www. zerowasteeurope.eu/), and 'the circular economy' [35], defined by the UK's Waste and Resources Action Programme as '.. an alternative to traditional linear economy (make, use, dispose) in which we keep resources in use as long as possible, extract the maximum value from them whilst in use, then recover and regenerate products and materials at the end of each service life' [36].

Moving towards a CE will rebalance trade-offs between resources used for production and accessible for consumption, leading to multiple social benefits. Reduced demand for primary materials will reduce energy consumption and thus $\mathrm{CO}_{2}$ emissions, increase energy security, reduce the demand for new energy generation capacity, and help meet formal obligations nationally (e.g., the UK 2008 Climate Change Act) and internationally (e.g., the 2016 Paris agreement). It will also reduce demand for water currently used in industrial and agricultural production processes, increasing domestic access to clean water. Much load on local transport systems is for the movement of raw materials and removal of waste; reducing the production of both and matching local waste arisings with secondary material requirements will ease pressure on roads and rail. In sum, systems that allow recovery of resources from wastes will increase the supply of valuable and essential resources, ultimately reducing their cost and providing more equal resource access. Accordingly, a focus on designing recyclability, reusability, and recoverability into products and processes would greatly increase equitable access to the value thereby created. It would also provide opportunities for new recovery businesses and drive innovation in existing industry, increasing employment and decreasing poverty. Arguably, all of these are key political ambitions globally and in the UK [5,37]. Moreover, using critical resources in a circular way reduces geopolitical risks associated with their unequal distribution, see, e.g., export bans and/or tariffs applied to Chinese REMs required by Japanese industries [38] and the EU's continuous monitoring of raw materials necessary for low-carbon technologies [39].

These economic systems are well developed theoretically, but their practical implementation requires

- advances in sciences (economics, environmental, engineering and social) to develop new processing technologies and business models;

- methodologies that can account for emissions to the biosphere and impacts on the environment, human health, and social wellbeing; and

- economic models that can assess the true (i.e., economic, social and environmental) costs and benefits of materials and wastes. 
Implementation also requires social and cultural changes in, e.g., regulatory frameworks, industrial practice, product design, and consumer behaviour. Mismatches in the scales of operation between waste producers, waste treatment operators, and the potential consumers of resources recovered from waste can impede the development of viable markets for recovered resources. Uncertainties surrounding ownership of many potentially valuable waste streams, rapid fluctuations in waste-derived resource prices and geographical constraints on the feasibility of waste reuse (e.g., dislocations between waste providers and new resource users) add further market distortions. The current waste management sector, in collaboration with designers, manufacturers and users, will play a key role in addressing these issues, becoming seen as custodians of resources rather than collectors of rubbish.

\section{Science and Technology}

Transforming the resource economy from a linear to a circular model requires the development of new approaches and technologies. At present, the recovery of physical resources such as minerals and nutrients from wastes is still limited. Haas et al. [40] analysed the circularity of the global economy in 2005, estimating that, of the 62 Gt materials processed annually, $13 \mathrm{Gt}$ entered the waste stream and only $4 \mathrm{Gt}$ was recycled. A large proportion of resources remain in stock, and is expected to grow as new infrastructure such as roads and buildings are realised. Many resources are used as energy carriers and are hence not available for material recycling. This indicates that the transition to a CE needs to be accompanied with the uptake of renewable and low-energy resource recovery solutions. Circularity could further benefit from an increased focus on eco-design [40].

\subsection{From End-of-Pipe Approaches to Whole System Design}

To increase circularity and enable resource recovery from waste, the focus needs to move from 'end-of-pipe' treatments to changes at the product design and manufacturing stages. Materials, components, and products must be brought to market that are more amenable to being reused, dismantled, and/or recycled, by considering how resources are transformed during each stage of the product life cycle from extraction through to disposal. Minimising impacts and maximising benefits will require that resource and waste management are integrated with each stage of the product life cycle (see Section 5) to prevent the dissipation of resources into waste.

For example, in polymer products, a major barrier to recycling is the use of multiple polymers in a single product that cannot be easily separated at the recycling stage. An 'end-of-pipe' response to this would be to develop technology that can separate the polymers for recycling; this will involve the use of energy-intensive physical, chemical, or thermal processes that use further resources. A system response would be to work with the producer to redesign the product to use a single polymer, or design it so that the different materials can be easily separated. This will make recycling easier, quicker, and more profitable for the waste processor, and provide the producer with a cheaper, cleaner, and more available stream of recycled feedstock; both actors in the system win, and the environmental impact is reduced.

Another large potential environmental threat comes from materials that have been relatively recently introduced in large quantities to the technosphere, such as the cocktail of elements used in IT and communications technologies, the rare earth metals used in high-performance electrical motors and generators, the lithium and cobalt compounds used in electrical storage systems, or the various high-performance composite materials introduced into the transport and power generation sectors [41,42]. Since such products-e.g., electric vehicles, wind turbines, computers and 'internet of things'-enabled products, and the ubiquitous cellphone-are not designed with any significant regard for the recovery of these critical and/or difficult to recycle materials at the end-of-life stage, they will, without careful management, eventually enter the biosphere. Knowledge of the environmental effects of these substances on biogeochemical pathways and ecotoxicity is still limited [15]. 
The design of new and future products should have durability, reusability, and recyclability as primary performance requirements. This needs to be in tune with the technological and processing capacity of recycling facilities, waste collection practices, and consumer behaviour. Harmonising the whole system from product design to manufacturing, product use, and recycling will enable an increased circularity of resource flows.

Nevertheless, large volumes of wastes are already landfilled. This volume of waste is likely to grow as countless resources that are not designed for circularity are already stockpiled in society such as in infrastructure. Hence, the need for end-of-pipe technologies will remain. However, focus should turn to low-energy recycling technologies, such as the exploitation of biogeochemical processes to recover resources from wastes, moving beyond the simple extraction of minerals to the creation of high-value functional materials. By manipulating the bio-geochemistry of waste deposits-i.e., encouraging naturally occurring microbes that inhabit these deposits to extract and concentrate resources-systems can be designed that are integrated with natural ecosystem processes, in contrast to the rapid, high-energy, urban-centric industrial processes currently dominating resource recovery $[43,44]$.

\subsection{Multi-Dimensional Value Assessments for Circular Supply Chains}

To ensure that resource recovery solutions truly contribute to rebalancing resource use within planetary and societal boundaries, new valuation approaches need to be developed. Resource management sits in broader contexts, including the effect of changing climates, economic globalisation, and growing human populations on increasingly complex supply chains, affecting food, water, and energy security at local, national, and global scales $[6,26]$. It is important to develop valuation methods that can appreciate and internalise all crucial factors that have influence on and/or are impacted by resource recovery from waste. It has been recognised by government and academia that a reliance on financial cost-benefit analysis (even if modified to include some consideration of social and/or environmental value) as the core of any decision-making process in infrastructure systems is doomed to deliver flawed strategies [45] that in the long run will not deliver value for taxpayers or investors. There is no reason to suspect that our resource recovery infrastructure should be any different [46].

Multi-dimensional value assessments include a move away from a sole focus on the financial viability of single processes and instead consider, e.g., ecosystem services, new business models, system-wide value creation and distribution, regulations, traceability and consumer perception [47]. They aim to analyse the creation, distribution, and dissipation of 'multidimensional value'-impacts and benefits in the environmental, technical, social, and economic domains-associated with each stage of the product life cycle. This can identify where interventions in the system need to be made that maximise overall value creation (i.e., benefits) and/or minimise overall value destruction (i.e., impacts) and plan suitable transition pathways towards sustainable resource recovery.

A wider socio-economic 'systems' perspective is also essential to removing barriers to improved resource recovery from waste. For example, recycling involves identifying suitable industries to receive the waste and thus impacts economic systems; collection involves changing behaviours to preserve the value of household waste and thus impacts social systems; changing design practices to add reusability and recyclability involves changing manufacturing processes and product perception and thus impacts both technical and cultural systems.

Decisions regarding the environmental trade-offs between alternative methods of avoiding, recycling, and/or treating waste are often made more difficult because evidence of (environmental) impacts of new waste technologies may be scarce and must be gathered from across multiple scientific disciplines and scales, complicating the analysis. Thus, the purported environmental benefits of various options (e.g., reduced air pollution, increased biodiversity, and more appropriate land use) can be hard to justify quantitatively. There is a need for tools supporting decision making in the absence of perfect environmental, economic, or social data. 
With considerable uncertainties regarding the emerging circular or cascading supply chains prevalent, a deterministic tool calculating the 'right' decisions would be misleading. Instead, a tool that supports collaboration for the exploration and formulation of sensible arguments for resource recovery solutions within the dynamic global environmental, social, technological, and economic contexts would be more suitable, enabling the integration and solution of various societal issues.

\section{Rebalancing Resource Recovery and Waste Overload}

The environmental and social boundaries and economic changes outlined in the preceding sections are evidently well-recognised throughout the political arena and industry. Key issues such as pollution, resource scarcity, and climate change have been underlined in mainstream society for decades (e.g., [48,49]). Importantly, businesses acknowledge the value of the CE; a third of CEOs globally are looking to take up circular models [50]. However, global progress towards sustainable waste and resource flows has been limited and, in fact, reverse trends have been observed since 1999/2000 [7]. Natural resource use has accelerated in the past 40 years, despite slowing economic and population growth. While material efficiency increased until the turn of the millennium, it has been decreasing ever since; driven by accelerated resource use and global production patterns shifting from countries with high to low resource efficiency.

This section turns towards enabling change in waste and resource management throughout society. The fact that $76 \%$ of UN SDGs contain targets with a direct bearing on waste and resource management indicates its relevance for a broad variety of societal factors and associated actors (Section 2). The preceding sections imply that the transition towards a CE within environmental and social boundaries involves multiple actors, including

- designers, manufacturers, consumers, and waste processers along the supply chain;

- academia to provide the evidence base, enabling technologies and analytical tools; and

- politicians and regulators to provide legislation that changes behaviours and supports markets, supported by NGOs where governments have failed.

Individual concerns, perceptions and knowledge of these actors need to be joined up through social debate, proposing increasingly coherent changes, linking concerns and solutions across multiple interests through social learning, leading to the construction of shared values, problem perceptions, and solution spaces that can function as 'windows of change' for radical transitions towards a CE [11,51]. Participatory governance is a known approach for such transition processes seeking to solve complex environmental problems involving multiple actors at multiple scales [52].

\subsection{Participatory Approaches for the Circular Economy}

Participatory governance involves stakeholder engagement processes, which can range from informing to listening, consulting, co-producing, co-deciding, and full autonomy [53,54] (Figure 3). Stakeholders should be engaged at levels appropriate to their influence and interest. This can be based on factors related to various types of capital, such as the possession of key information, finance, human resources, social contacts that can be mobilised for problem solving, political power, or market positions. Aside from the necessity to engage stakeholders that have key ingredients required to identify and solve particular problems, higher participation levels have also been proposed as a mechanism to create greater commitment amongst stakeholder in power to deliver the envisioned societal changes. 


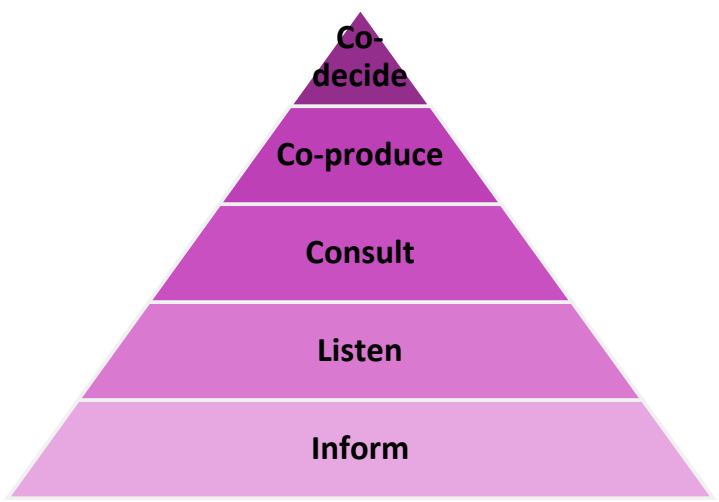

Figure 3. In the transition towards waste and resource management, relevant stakeholders need to be engaged and collaborate at participation levels ranging from informing to co-deciding.

Participation processes can be used to explore perceptions from multiple stakeholders regarding a particular problem. Stakeholders share perceptions that are negotiated to reframe the problem, starting to converge stakeholder views. In this way, shared solution spaces can be identified or forged, providing a basis to frame radical, transformative changes such as those required for the transition towards a sustainable CE.

Participatory governance has been associated with a range of interconnected social benefits. Through the shared production of knowledge and solutions, participation processes can $[52,55,56]$ :

- contribute to greater social inclusiveness and empowerment of stakeholders;

- promote social learning and thereby strengthen connections between diverse societal segments and transform adversarial relations (for example, between proponents of environmental protection and economic growth);

- increase the quality of information and solutions, not least due to embeddedness into specific (geographic) contexts; and

- increase acceptance and commitment to the solutions that can also contribute to prevention of implementation issues and consequently reduce costs when bringing a solution into practice.

In sum, higher stakeholder engagement levels should positively impact the quality, legitimacy, speed, and cost with which solutions are implemented. Given this range of benefits that are important for sustainable development, it is no surprise that participation processes have been recommended by influential global actors in addressing social and environmental issues in an integrated manner $[5,9,24,55]$.

The academic community can adapt these techniques to contribute to developing transformative changes through participatory action research (PAR). In this way, academia can contribute to knowledge for, and the actual implementation of, sustainable development and CE; an area of work in waste and resource management that requires urgent attention [57-60]. PAR approaches have the dual purpose of bringing societal change and contributing to scientific progress [61]. A diversity of stakeholders is involved in achieving both purposes. PAR usually develops through a cycle of activities, although exact descriptions of the approaches differ [61,62] (Figure 4). A stakeholder group is formed (1), issues are identified and analysed followed by identification of solutions and opportunities for change (2), solutions are shared and discussed collectively after which each stakeholder reflects upon the proposed change and then implements it (3), and the PAR cycle concludes with evaluation of the process (4). In some cases, stakeholders may decide in the fourth stage that further societal changes are needed, possibly with an extended/adapted network of participants, leading to the start of a new PAR cycle. 


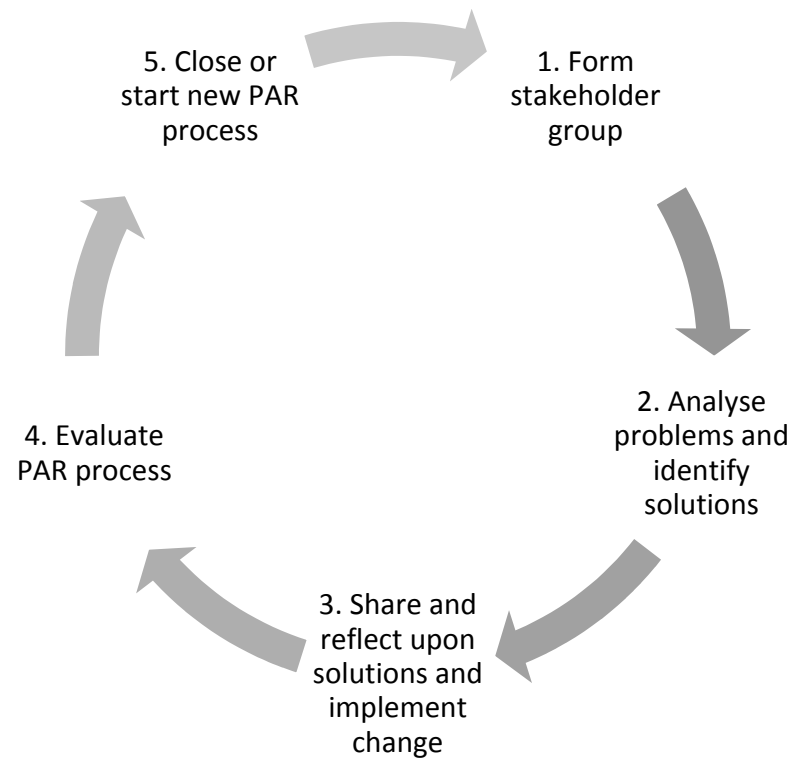

Figure 4. Participatory Action Research (PAR) cycle [61,62].

Diverse stakeholder involvement from across society is key to PAR approaches. Identification of relevant stakeholders is important (for an overview of stakeholder analysis techniques, see [63]) to enable more plural processes, leading to more learning and, consequently, more change [55]. In natural resource management, more diversity is linked to ecosystem stability, while in participatory governance it is associated with change. This apparent contradiction can be reconciled with the concept of proximity, which theorises optima for various types of absolute and relative proximity including the cognitive differences between actors engaged in innovation and learning [60,64]. Some cognitive diversity is necessary to enable learning, while too much diversity can pose barriers to learning and, consequently, (societal) change. Waste and resource management would form an interesting case to test the hypothesis whether optima for pluralism in PAR exist and, as suggested in various industrial ecology publications and conferences, varies depending on contextual conditions.

\subsection{Participation Strategy of the Resource Recovery from Waste Programme}

The Resource Recovery from Waste programme (RRfW) [6] draws upon PAR methods to achieve its strategic purpose striving for a paradigm shift in waste and resource management in the UK. The participation strategy was initiated with a three-stage process:

1. Stakeholder and network analysis

2. Understanding learning and innovation pathways

3. Detailing engagement activities

In 2014, RRfW started with 86 formal academic, industry, and government partners. A further 73 organisations expressed support or interest in the programme and its projects. A stakeholder analysis of programme partners identified organisations that were most specialised for, and were the most likely to impact on, waste and resource policy. A further social network analysis was used to identify pathways to impact the UK government and industrial practice. The stakeholder and network analyses revealed that it was already a large network, with strong non-academic representation of $50 \%$ industry and $10 \%$ government partners as well as many partners working in knowledge exchange, which could support our dissemination capacity. However, it was a very loose-knit low density network and, arguably, to benefit from the collective ability to develop, share and take up knowledge for radical economic change, would require stakeholder integration to form a transdisciplinary community of people working for the transition towards a CE. It also became clear that government bodies outside 
the waste and resource management sphere, but with a strong influence on the sector, were not yet within the programme's network of direct contacts. Hence, strategic targets for network expansion were set and achieved alongside the development and delivery of the participation strategy.

The ways in which government and industry partners were learning and innovating were analysed to ensure RRfW was engaging them in the right manner to change practices and mentality regarding waste and resource management. The waste and reprocessing industry was surveyed at the Resource and Waste Management exhibition covering questions on the following [65]:

1. learning and innovation mechanisms;

2. openness to external (compared to in-house generated) knowledge;

3. the types of contacts considered reliable and trustworthy when gathering information about changing business practices, business improvements, and innovations; and

4. the types and credibility of communication channels used when exchanging information with the identified knowledge providers.

Similarly, government perspectives on learning and innovation through collaboration with academia were captured through semi-structured interviews that were part of the co-creation of a vision and approach for waste and resource management in the UK (further discussed below) [66].

The strategic network expansion targets, formed on the basis of the stakeholder- and network analyses, and the results on understanding learning- and innovation processes by government and industry were integrated with engagement activities. Engagement activities covered the full spectrum of the participation ladder, from informing to co-deciding. The philosophy behind this approach is to capture a wide audience of existing and new partners with activities to inform stakeholders through, for example, social media, networking and presenting at events, and scientific and professional publications, and, after this initial contact, to engage them in activities at increasingly high participation levels. This involves activities to consult and be consulted such as hosting events and membership of relevant industry and government committees, to co-produce research through hosting workshops and placements, and finally to co-decide on research from design to dissemination through co-authoring publications and the contents of industry and regulatory standards. In theory, this increasing level of participation should create a sense of ownership for, and commitment to, the research outcomes, leading to a higher level of uptake during and upon completion of RRfW. This should contribute to the strategic purpose of RRfW, to realise change in mentality, business practices, and policies and regulations in the waste and resource management landscape of the UK.

RRfW will run long enough to cover two PAR cycles. After discussion with key stakeholders, the first PAR cycle started to focus on the creation of a shared vision and approach for waste and resource management in the UK, which soon focused on CE. This activity has a dual purpose for RRfW: (1) engage stakeholders in creating a vision and approach for the uptake of CE and RRfW technologies, and (2) deepen the understanding of how stakeholders think and change, their drivers, etc. to sketch out transition pathways, including mentality and practice changes. The first part is about understanding what needs to change and the actions required to get there, and the second part is about understanding how stakeholders can be guided to work in the same direction. The co-creation process will cover four stages, capturing academic, government, and industry perspectives, which will then be integrated in the fourth and final stage. Findings will be shared throughout the co-creation process. Moreover, aptitude and opportunities for the second PAR cycle will be monitored.

Early engagement successes include the establishment of a LinkedIn network with over 300 key actors in waste and resource management. Industry and government have been regularly engaged through presentations and networking at 1-2 events per month. This stream of activities to inform contacts built up to a successful trans-disciplinary RRfW conference with academic, industry, and government participation, followed by a workshop facilitating social debate between these actors. Co-creation activities for a vision and approach towards the CE were carried out with our academic and government contacts, as described above. The resulted in a conference article co-authored with 
government partners for the International Sustainable Development Research Society conference 2017 [67], showing a high level of identification with RRfW results from existing and new contacts such as in the Department for Environment, Food and Rural Affairs (DEFRA), Department for Business, Energy and Industrial Strategy (BEIS), Zero Waste Scotland (ZWS), and the Environment Agency (EA). The co-creation process also sparked new contacts with the National Infrastructure Committee (NIC) and identified a demand for a review of CE infrastructure in the UK, which was met within RRfW [46]. RRfW also actively contributed to government and industry debate around CE through workshops hosted by BEIS (on CE strategy for energy intensive industries) and NIC (on waste management infrastructure priorities) as well as consultations and committees such as the BS8001 standard for circular economy and the Policy Connect 'Brexit series' event on waste policy. Emerging contacts were galvanised in seven transdisciplinary projects, also bringing together researchers from across our network, building a community around resource recovery to enable reciprocal communication and uptake of RRfW results. Last but not least, RRfW is starting to see the first signs that government and industry are internalising research outcomes, through presentations, strategies, and reports produced by our non-academic partners.

\section{Conclusions}

This article has demonstrated that waste and resource management plays a key role in sustainable development within environmental and societal boundaries. With various boundaries crossed already, a transition towards a circular economy is urgently needed. To envision and realise the required changes, multiple actors from across society need to be engaged. Academia can contribute through participatory action research on the circular economy. In this way, shared solutions can be identified and detailed, creating a window of opportunity for the transition towards a circular economy that contributes to a resilient environment and human well-being.

Acknowledgments: We gratefully acknowledge the funding received from NERC, ESRC, and DEFRA for the Resource Recovery from Waste (RRfW) programme under grant code CVORR NE/L014149/1; led by the Programme Coordination Team of RRfW-Alfonso-Lag Brotons, Lynne Macaskie, Rachel Marshall, William Mayes, Ian Head, Devin Sapsford, Kirk Semple, and Ana Suarez (in addition to Phil Purnell and Anne Velenturf). We also thank Louise Walker and Sally Reid for their input. Finally, we thank the University of Leeds for covering the open access publication fees.

Author Contributions: The RRfW Programme Coordination Team initiated the article idea; Anne P. M. Velenturf and Phil Purnell consecutively outlined various storylines and wrote the article; Anne P. M. Velenturf finalised the article.

Conflicts of Interest: The authors declare no conflict of interest. While the founding sponsors did task the RRfW Programme Coordination Team with the formulation of a vision shared across all projects in our programme, the formulated position is based on views expressed within our team only and the decision to publish it has been made by the authors.

\section{References}

1. Dobbs, R.; Oppenheim, J.; Thompson, F.; Brinkman, M.; Zornes, M. Resource Revolution: Meeting the World's Energy, Materials, Food, and Water Needs; McKinsey Quarterly and Company: New York, NY, USA, 2011.

2. United Nations Environment Programme (UNEP). Decoupling: Natural Resource Use and Environmental Impacts from Economic Growth; Fischer-Kowalski, M., Swilling, M., von Weizs€acker, E.U., Ren, Y., Moriguchi, Y., Crane, W., Krausmann, F., Eisenmenger, N., Giljum, S., Eds.; A Report of the Working Group on Decoupling to the International Resource Panel; UNEP: Nairobi, Kenya, 2011.

3. Morgan, J. The Great Resource Price Shock; Green Alliance: London, UK, 2014.

4. United Nations Environment Programme (UNEP); International Solid Waste Association (ISWA). Global Waste Management Outlook. 2015. Available online: http://apps.unep.org/publications/index.php? option=com_pub\&task=download\&file=011782_en (accessed on 4 July 2016).

5. United Nations (UN). Transforming Our World: The 2030 Agenda for Sustainable Development; UN: New York, NY, USA, 2015. 
6. Natural Environment Research Council (NERC). Resource Recovery from Waste Science and Implementation Plan 2012-2018-Version 1.3, Jan 2014; NERC: Swindon, UK, 2014. Available online: http://www.nerc.ac.uk/ research/funded/programmes/waste/science-and-implementation-plan/ (accessed on 4 July 2016).

7. United Nations Environment Programme (UNEP). Global Material Flows and Resource Productivity: Assessment Report for the UNEP International Resource Panel. 2016. Available online: http:// unep.org/documents/irp/16-00169_LW_GlobalMaterialFlowsUNEReport_FINAL_160701.pdf (accessed on 15 August 2016).

8. Crutzen, P.J. Geology of mankind: The Anthropocene. Nature 2002, 415, 23. [CrossRef] [PubMed]

9. Millennium Ecosystem Assessment (MEA). Ecosystems and Human Well-Being: Synthesis; Island Press: Washington, DC, USA, 2005. Available online: http://www.millenniumassessment.org/documents/ document.356.aspx.pdf (accessed on 4 July 2016).

10. Townsend, C.R.; Begon, M.; Harper, J.L. Essentials of Ecology; Blackwell Publishing: Hoboken, NJ, USA, 2000.

11. Chapin, F.S.; Kofinas, G.P.; Folke, C. Principles of Ecosystem Stewardship: Resilience-Based Natural Resource Management in a Changing World; Springer: New York, NY, USA, 2009.

12. Rockström, J.; Steffen, W.; Noone, K.; Persson, Å.; Chapin, F.S., III; Lambin, E.; Lenton, T.; Scheffer, M.; Folke, C.; Schellnhuber, H.J.; et al. Planetary boundaries: Exploring the safe operating space for humanity. Ecol. Soc. 2009, 14, 32.

13. Steffen, W.; Richardson, K.; Rockström, J.; Cornell, S.E.; Fetzer, I.; Bennett, E.M.; Biggs, R.; Carpenter, S.R.; de Vries, W.; de Wit, C.A.; et al. Planetary boundaries: Guiding human development on a changing planet. Science 2015, 347, 1259855. [CrossRef] [PubMed]

14. Allwood, J.M.; Cullen, J.M.; Carruth, M.A.; Cooper, D.R.; McBrien, M.; Milford, R.L.; Moynihan, M.C.; Patel, A.C. Sustainable Materials: With Both Eyes Open; Cambridge University Press: Cambridge, UK, 2012. Available online: http:/ / www.withbotheyesopen.com/index.html (accessed on 4 July 2016).

15. Natural Environment Research Council (NERC). Sustainable Use of Natural Resources-Theme Action Plan 3; NERC: Swindon, UK, 2012. Available online: http:// webarchive.nationalarchives.gov.uk/20120703112514/ http:/www.nerc.ac.uk/research/themes/tap/documents/tap-natural-resources-p3.pdf (accessed on 4 July 2016).

16. United Nations Environment Programme (UNEP). Waste and Climate Change: Global Trends and Strategy Framework; UNEP: Nairobi, Kenya, 2010. Available online: http:/ / www.unep.or.jp/ietc/Publications/spc/ Waste\&ClimateChange/Waste\&ClimateChange.pdf (accessed on 4 July 2016).

17. Gilbert, N. The disappearing nutrient. Nature 2009, 461, 716-718. [CrossRef] [PubMed]

18. Rowden, J.; Schiller, F.; Penn, A. Redesigning Phosphorous Flows. Soil Requirements on Welfare and Health 44/45:10-12. 2013. Available online: http:/ / www.academia.edu/7270538/Redesigning_phosphorous_flows (accessed on 4 July 2016).

19. Mekonnen, M.M.; Hoekstra, A.Y. National Water Footprint Accounts: The Green, Blue and Grey Water Footprint of Production and Consumption; Value of Water Research Report Series No. 50; UNESCO-IHE: Delft, The Netherlands, 2011.

20. Kartal, B.; Kuenen, J.G.; Van Loosdrecht, M.C.M. Sewage treatment with Anammox. Science 2010, 328, 702-703. [CrossRef] [PubMed]

21. Le Corre, K.S.; Valsami-Jones, E.; Hobbs, P.; Parsons, S.A. Phosphorus recovery from wastewater by struvite crystallization: A review. Crit. Rev. Environ. Sci. Technol. 2009, 39, 433-477. [CrossRef]

22. International Panel on Climate Change (IPCC). Climate Change 2014: Impacts, Adaptation, and Vulnerability; Contribution of the Working Group II to the Fifth Assessment Report of the Intergovernmental Panel on Climate Change; Cambridge University Press: Cambridge, UK, 2014.

23. United Nations Environment Programme (UNEP). Climate Change and Human Rights. 2015. Available online: http:/ / www.unep.org/delc/HumanRightsandTheEnvironment/tabid/54409/Default. aspx (accessed on 4 July 2016).

24. Office of the United Nations High Commissioner for Human Rights (OHCHR); United Nations Environment Programme (UNEP). Human Rights and the Environment. 2012. Available online: http://www.unep. org/delc/Portals/119/JointReportOHCHRandUNEPonHumanRightsandtheEnvironment.pdf (accessed on 4 July 2016).

25. Raworth, K. A Safe and Just Space for Humanity: Can We Live within the Doughnut? Oxfam International: Oxford, UK, 2012. 
26. 10YFP. The 10 Year Framework of Programmes on Sustainable Consumption and Production; UNEP: Nairobi, Kenya, 2012. Available online: http://www.scpclearinghouse.org/sites/default/files/10yfp_general_brochure_ february_2017-.pdf (accessed on 4 July 2016).

27. Royal College of Physicians (RCP); Royal College of Paediatrics and Child Health (RCPCH). Every Breath We Take: The Lifelong Impact of Air Pollution; The Lavenham Press: Lavenham, UK, 2016.

28. International Solid Waste Association (ISWA). A Roadmap for Closing Waste Dumpsites: The World's Most Polluted Places. 2016. Available online: http:/ / www.iswa.org/fileadmin/galleries/About\%20ISWA/ISWA_ Roadmap_Report.pdf (accessed on 12 September 2016).

29. Wilson, D.C.; Velis, C.; Cheeseman, C. Role of informal sector recycling in waste management in developing countries. Habitat Int. 2006, 30, 797-808. [CrossRef]

30. Bilitewski, B.; Barbra, R.M.; Barcelo, B. Global Risk Based Management of Chemical Additives I: Production, Usage and Environmental Occurrence; Springer: Berlin, Germany, 2012.

31. Smith, S.R. Organic contaminants in sewage sludge (biosolids) and their significance for agricultural recycling. Philos. Trans. R. Soc. Lond. A 2009, 367, 4005-4041. [CrossRef] [PubMed]

32. Slater, F.R.; Singer, A.C.; Turner, S.; Barr, J.J.; Bond, P.L. Pandemic pharmaceutical dosing effects on wastewater treatment. FEMS Microbiol. Lett. 2011, 315, 17-22. [CrossRef] [PubMed]

33. Department for Environment, Food and Rural Affairs (DEFRA). Guidance on Applying the Waste Hierarchy; DEFRA: York, UK, 2011. Available online: https:/ /www.gov.uk/government/uploads/system/uploads / attachment_data/file/69403/pb13530-waste-hierarchy-guidance.pdf (accessed on 4 July 2016).

34. Collier, P.; Alles, C.M. Materials Ecology. Science 2010, 330, 919-920. [CrossRef] [PubMed]

35. Ghisellini, P.; Cialani, C.; Ulgiati, S. A review on circular economy: The expected transition to a balanced interplay of environmental and economic systems. J. Ind. Ecol. 2016, 114, 11-32. [CrossRef]

36. WRAP. Waste and Resources Action Partnership, WRAP and the Circular Economy. 2016. Available online: http:/ / www.wrap.org.uk/about-us/about/wrap-and-circular-economy (accessed on 4 July 2016).

37. House of Commons. UK Implementation of the Sustainable Development Goals; House of Commons: London, UK, 2016. Available online: https:/ / www.publications.parliament.uk/pa/cm201617/cmselect/cmintdev/ 103/103.pdf (accessed on 15 August 2016).

38. BBC. 2012. Available online: http:/ / www.bbc.co.uk/news/business-17348648 (accessed on 4 July 2016).

39. European Union (EU). Critical Raw Materials. 2017. Available online: https:/ / ec.europa.eu/growth/sectors / raw-materials / specific-interest/critical_en (accessed on 12 June 2017).

40. Haas, W.; Krausmann, F.; Wiedenhofer, D.; Heinz, M. How circular is the global economy? An assessment of material flows, waste production, and recycling in the European Union and the world in 2005. J. Ind. Ecol. 2015, 19, 765-777. [CrossRef]

41. Ortegon, K.; Nies, L.F.; Sutherland, J.W. Preparing for end of service life of wind turbines. J. Clean. Prod. 2013, 39, 191-199. [CrossRef]

42. Topham, E.; McMillan, D. Sustainable decommissioning of an offshore wind farm. Renew. Energy 2017, 102, 470-480. [CrossRef]

43. Gomes, H.I.; Mayes, W.M.; Rogerson, M.; Stewart, D.I.; Burke, I.T. Alkaline residues and the environment: A review of impacts, management practices and opportunities. J. Clean. Prod. 2016, 112, 3571-3582. [CrossRef]

44. Sapsford, D.; Cleall, P.; Harbottle, M. In Situ resource recovery from waste repositories: Exploring the potential for mobilization and capture of metals from anthropogenic ores. J. Sustain. Metall. 2017, 3, 375-392. [CrossRef]

45. HMT. HM Treasury and Infrastructure UK Green Book Supplementary Guidance: Valuing Infrastructure Spend; HM Treasury: London, UK, 2015. Available online: https://www.gov.uk/government/publications/greenbook-supplementary-guidance-valuing-infrastructure-spend (accessed on 4 July 2016).

46. Purnell, P. On a voyage of recovery: A preliminary review of the UK's resource recovery from waste infrastructure. Unpublished work.

47. Iacovidou, E.; Velis, C.A.; Purnell, P.; Zwirner, O.; Brown, A.; Hahladakis, J.; Millward-Hopkins, J.; Williams, P.T. Metrics for optimising the multi-dimensional value of resources recovered from waste in a circular economy: A critical review. J. Clean. Prod. 2017, 166, 910-938. [CrossRef] 
48. Meadows, D.H.; Meadows, D.L.; Randers, J.; Behrens, W.W. The Limits to Growth; A Report for the Club of Rome's Project on the Predicament of Mankind; Universe Books: New York, NY, USA, 1972. Available online: http:/ / www.donellameadows.org/wp-content/userfiles/Limits-to-Growth-digital-scan-version. pdf (accessed on 15 August 2016).

49. Brundtland, G.H. Report of the World Commission on Environment and Development: Our Common Future. 1987. Available online: http://www.un-documents.net/our-common-future.pdf (accessed on 15 August 2016).

50. Accenture. The UN Global Compact-Accenture CEO Study on Sustainability; Accenture: Dublin, Republic of Ireland, 2013. Available online: https://www.unglobalcompact.org/docs/news_events/8.1/UNGC_ Accenture_CEO_Study_2013.pdf (accessed on 15 August 2016).

51. Everard, M.; Reed, M.S.; Kenter, J.O. The ripple effect: Institutionalising pro-environmental values to shift societal norms and behaviours. Ecosyst. Serv. 2016, 21, 230-240. [CrossRef]

52. Reed, M.S. Stakeholder participation for environmental management: A literature review. Biol. Conserv. 2008, 141, 2417-2431. [CrossRef]

53. Arnstein, S.R. A ladder of citizen participation. J. Am. Inst. Plan. 1969, 35, 216-224. [CrossRef]

54. Breman, B.; Pleijte, M.; Ouboter, S.; Buijs, A. Participatie in Waterbeheer: Een vak Apart; Alterra Wageningen UR: Wageningen, The Netherlands, 2008.

55. Roldán, A.M. Political regime and learning outcomes of stakeholder participation: Cross-national study of 81 biosphere reserves. Sustainability 2017, 9, 553. [CrossRef]

56. Richards, C.; Blackstock, K.; Carter, C. Practical Approaches to Participation, 2nd ed.; SERG Policy Brief Number 1; Carter, C.E., Spash, C.L., Eds.; Socio-Economic Research Group: Hilton Head Island, SC, USA, 2007.

57. Bulkeley, H.; Watson, M.; Hudson, R. Modes of governing municipal waste. Environ. Plan. A 2007, 11, 2733-2753. [CrossRef]

58. Lehtoranta, S.; Nissinen, A.; Mattila, T.; Melanen, M. Industrial symbiosis and the policy instruments of sustainable consumption and production. J. Clean. Prod. 2011, 19, 1865-1875. [CrossRef]

59. Koskela, S.; Matilla, T.; Antikainen, R.; Mäenpää, I. Identifying Key Sectors and Measures for a Transition towards a Low Resource Economy. Resources 2013, 2, 151-166. [CrossRef]

60. Velenturf, A.P.M.; Jensen, P.D. Promoting industrial symbiosis: Using the concept of proximity to explore social network development. J. Ind. Ecol. 2016, 20, 700-709. [CrossRef]

61. Bacon, C.; Mendez, V.E.; Brown, M. Participatory Action Research and Support for Community Development and Conservation: Examples from Shade Coffee Landscapes in Nicaragua and El Salvador; Center Research Brief \#6; Center for Agroecology and Sustainable Food Systems, University of California: Santa Cruz, CA, USA, 2005.

62. Defoer, T.; De Groote, H.; Hilhorst, T.; Kante, S.; Budelman, A. Participatory action research and quantitative analysis for nutrient management in southern Mali: A fruitful marriage? Agric. Ecosyst. Environ. 1998, 71, 215-228. [CrossRef]

63. Reed, M.S.; Graves, A.; Dandy, N.; Posthumus, H.; Hubacek, K.; Morris, J.; Prell, C.; Quinn, C.H.; Stringer, L.C. Who's in and why? A typology of stakeholder analysis methods for natural resource management. J. Environ. Manag. 2009, 90, 1933-1949. [CrossRef] [PubMed]

64. Boschma, R. Proximity and innovation: A critical assessment. Reg. Stud. 2005, 39, 61-74. [CrossRef]

65. Velenturf, A. P. M.; Iacovidou, E. Learning and Innovating in Waste Management. Resource Recovery from Waste. 2016. Available online: https://www.linkedin.com/pulse/learning-innovating-waste-managementrecovery-from-waste-programme (accessed on 26 September 2016).

66. Resource Recovery from Waste. 2017. Available online: https://www.linkedin.com/pulse/towards-sharedvision-waste-resource-management-1-resource (accessed on 23 January 2017).

67. Velenturf, A.P.M.; Purnell, V.P.; O'Callaghan, K.; Tregent, M.; Ferguson, J.; Woodend, A.; Davies, L.; Geveke, A.; McGregor, L.; Jamieson, H.; et al. Co-producing a vision and approach for the transition towards a circular economy: Perspectives from government partners. In Proceedings of the International Sustainable Development and Research Society Conference, Bogota, Colombia, 14-16 June 2017. Available online: http:/ / programme.exordo.com/isdrs2017/delegates/presentation/379/ (accessed on 14 June 2017).

(C) 2017 by the authors. Licensee MDPI, Basel, Switzerland. This article is an open access article distributed under the terms and conditions of the Creative Commons Attribution (CC BY) license (http:/ / creativecommons.org/licenses/by/4.0/). 